\title{
ПОЗИТИВНЫЕ КАЧЕСТВА В ПСИХОЛОГИИ ПОБЕДИТЕЛЯ
}

\author{
Шумахер Марина Ивановна \\ магистрант \\ Федеральное государственное автономное образовательное учреждение \\ высшего образования «Белгородский государственный национальный \\ исследовательский университет» \\ Воронков Александр Владимирович \\ кандидат педагогических наук, доиент \\ заведуюший кафедрой спортивных дисцинлин \\ Федеральное государственное автономное образовательное учреждение \\ высшего образования «Белгородский государственный национальный \\ исследовательский университет» \\ Бражник Екатерина Андреевна \\ студент \\ Федеральное государственное автономное образовательное учреждение \\ высшего образования «Белгородский государственный национальный \\ исследовательский университет» \\ Агафонов Иван Владимирович \\ студент \\ Федеральное государственное автономное образовательное учреждение \\ высшего образования «Белгородский государственный национальный \\ исследовательский университет»
}

\begin{abstract}
Аннотация. Статья психология победителя в спорте дает нам понимание того, из каких положительных качеств нам необходимо выстраивать психологию победителя. В статье представлены 10 основах качеств, которые присущи победителю, все эти качества распространяются абсолютно на любой вид спорта и подходят как высоко квалифицированному спортсмену так и новичку.

Abstract. The article psychology of the winner in sports gives us an understanding of what positive qualities we need to build the psychology of the winner. The article presents 10 basic qualities that are inherent in the winner, all these qualities apply to absolutely any sport and are suitable for both highly qualified athletes and beginners.
\end{abstract}

Ключевые слова: спорт, спортсмен, психология победителя, победа, качества победителя.

Keywords: sport, athlete, winner's psychology, victory, winner's qualities.

Введение. Одним из важнейших факторов победы в спорте наряду с техникой и физической подготовкой является психологический фактор. Секрет психологии победителя прост: в его основе лежит привычка к позитивному мышлению. Все, что необходимо знать спортсмену,- это основы образа мыслей и поведения, присущие всем людям, добивающимся успеха, воспринимать и применять эти основы как неотъемлемую часть своей повседневной жизни, что и поможет достичь значительных успехов во всех сферах деятельности, включая спорт. Психология победы базируется на следующих основных положениях:

- спортсмены - чемпионы имеют сходные черты, отличающие их от остальных;

- эти черты, определяющие способность побеждать, могут быть приобретены;

- вы - тот, кем сами себя считаете. Вы - продукт доминирующих в вас представлений;

- ваше поведение и ваши движения выражают ход ваших мыслей;

- позитивное мышление помогает выработать новое желаемое отношение к определенной проблеме [1,3,4].

Любое позитивное мышление или программа самосовершенствования - это выработанный для самого себя план.

Десять основных качеств, присущих победителю

1. Позитивная надежда на свои силы.

Победители, как правило, проявляют неувядающий оптимизм во всем, чтобы они не делали. Другими словами, победители ищут, ожидают и обычно добиваются максимальных результатов в том, за что они взялись. Энтузиазма и возбужденности у них всегда предостаточно даже когда ситуация может оказаться неблагоприятной Выдающиеся личности рассчитывают победить заранее. Они исходят из убеждения, что жизнь - это предназначение, обеспечиваемое самим собой, что человек обычно добивается того, чего от себя ожидает [3].

2. Позитивная самомотивация.

Победители обладают поразительной внутренней силой, которая помогает трансформировать позитивную надежду на свои силы в действие. Победители руководствуются огромным желанием быть первым, и это - их сокровенное желание. Более того, победители знают, что они станут тем или достигнут того, о чем больше всего 
думают. Поэтому постоянно побеждающие спортсмены подменяют силу страха силой желания и всегда сосредотачиваются не на проблеме, а на способе ее решения [4].

3. Позитивное представление о себе.

Победители рисуют для себя победу заранее. Они воспринимают представление о себе, как подсознательное устройство, определяющее ход жизни. Вы не можете сделать или достичь чего-то на практике, если вы в своем представлении этого сделать не можете. Мешает добиться какой то цели не ваша неспособность, а ваше неправильное, заниженное представление о себе, своих возможностях [3,5].

4. Позитивное самонаправление.

Победители превращают позитивное представление о себе в план действий, направленный на достижение определенной цели. Они рассматривают успех, как постепенное ежедневное целей, соответствующих возможностям данного индивида. Победители испытывают огромное удовлетворение и радость, когда активно идут к намеченной цели. Он всегда сосредотачивается на достижении поставленной цели [2,4].

5. Позитивный самоконтроль.

Победители считают, что все достижения в жизни зависят от них самих. Они осознают, что способны достичь значительного большего, чем можно предположить. Победители контролируют все происходящие события и сами вершат свои судьбы [1].

6. Позитивная самодисциплина.

Самодисциплина - это особое умение тренироваться в воображении, в то время. как тело в этой тренировке не участвует. Эта тренировка в воображении способностей и качеств, даже если пока они недосягаемы на самом деле. Мысль переходит в привычку, и победители сознательно направляют свои мысли на то, чтобы выработать привычку добиваться высоких достижений, что характеризует настоящего чемпиона [1].

7. Позитивное чувство собственного достоинства.

У победителей всегда обострено чувство собственного достоинства, чувство уважения к себе и к своему делу. Победители осознают свою неповторимость, вырабатывают и поддерживают высокие требования к самим себе и к тому, что они делают. Залог успеха не столько во внешних факторах, сколько в глубокой вере в собственные возможности. Победители демонстрируют, что они являются продуктом своих собственных усилий, а не окружающих обстоятельств [5].

8. Позитивная самооценка.

Победители стремятся полностью познать себя и способны посмотреть на себя с другой стороны. Победители руководствуются принципом твоя победа - моя победа. Они часто помогают другим людям и дорожат своим временем, ценят близких им людей, бескорыстно помогают, зная, что ничего не получат взамен [4].

9. Позитивное самосознание.

Самосознание в нормальном понимании - это объективное отношение к себе. Победители не подсмеиваются над собой, они воспитывают в себе способность аккуратно и объективно оценивать себя. победители всегда знают насколько малы на самом деле их знания, но стремятся узнать больше. Они прекрасно понимают, что все пределы существуют прежде всего в воображении самого человека [3].

10. Позитивная способность производить впечатление.

Победители в повседневной жизни ежедневно программируют свои поступки таким образом, чтобы лучше выглядеть, лучше ходить, лучше разговаривать, слушать, реагировать. Победители предают большее значение первому впечатлению. Настоящие чемпионы планируют успех, но не хвастаются этим [2].

Вывод. Быть настоящим победителем - вовсе не значит сделать то или другое однажды. Это образ жизни! Победа - это не случайное явление, это - нечто постоянное. Польза «позитивных качеств в психологии победителя» в конечном итоге будет зависеть от того, какую часть этих рекомендаций вы воспримите и используете в качестве составной части вашего собственного отношения к жизни.

\section{Литература}

1. Жуина Д. В., Зазыкин В. Г., Майдокина Л. Г. Психолого-акмеологические аспекты психологии победителя // Теория и практика физической культуры. 2015. № 4. С. 47-48.

2. Загайнов Р. М. Психология современного спорта высших достижений. М.: Советский спорт, 2012.

3. Зациорский В. М. Физические качества спортсмена. М.: Советский спорт, 2009.

4. Майдокина Л.Г. Развитие саморегуляции спортсмена в системе его психологической подготовки / Л.Г. Майдокина, О.В. Кудашки-на // Теория и практика физ. культуры. - 2014. - № 8. - С. 18-21.

5. Федосеенков А.В., Ермилова В.А., Местоев И.Ю. Роль воображения и интуиции в познавательном процессе. Наука молодых - будущее России Сб. научных статей 2-й Международной научной конференции перспективных разработок молодых ученых. В 5-ти томах. 2017. С. 320. 


\section{References}

1. Zhuina D. V., Zazy`kin V. G., Majdokina L. G. Psixologo-akmeologicheskie aspekty` psixologii pobeditelya // Teoriya i praktika fizicheskoj kul`tury`. 2015. № 4. S. 47-48.

2. Zagajnov R. M. Psixologiya sovremennogo sporta vy`sshix dostizhenij. M.: Sovetskij sport, 2012.

3. Zaciorskij V. M. Fizicheskie kachestva sportsmena. M.: Sovetskij sport, 2009.

4. Majdokina L.G. Razvitie samoregulyacii sportsmena v sisteme ego psixologicheskoj podgotovki / L.G. Majdokina, O.V. Kudashki-na // Teoriya i praktika fiz. kul`tury`. - 2014. - № 8. - S. 18-21.

5. Fedoseenkov A.V., Ermilova V.A., Mestoev I.Yu. Rol voobrazheniya i intuicii v poznavatel’nom processe. Nauka molody`x - budushhee Rossii Sb. nauchny`x statej 2-j Mezhdunarodnoj nauchnoj konferencii perspektivny`x razrabotok molody`x ucheny`x. V 5-ti tomax. 2017. S. 320. 